\title{
Re Hungarian again
}

\author{
Aniko Csirmaz \\ University of Utah \\ aniko.csirmaz@utah.edu
}

\begin{abstract}
This paper is concerned with repetitive adverbials in Hungarian. It presents an overview of the different Hungarian equivalents of again, addressing their properties and their relevance. One of the goals of this paper is descriptive; it offers a systematic description of Hungarian repetitives. In addition, it provides evidence for two major claims. First, meaning differences (including the restitutive - repetitive ambiguity) are due to structural rather than lexical differences. Second, repetitives do not form a homogeneous set. The possible scope positions and in some cases, the denotation, of repetitive adverbials differs. This difference, in general, cannot be predicted from the morphological makeup of the repetitives, so an independent specification of the unexpected properties is necessary.
\end{abstract}

Keywords: repetitive adverbials; variation; scope; interpretation

\section{Introduction}

Repetitive adverbials have been discussed previously from a number of perspectives. Before discussing the issues, let us briefly consider the basic interpretation of repetitive adverbials such as again. A sentence containing again generally requires two relevant events.

(1) Fred read the book again.

With again, the asserted event follows a presupposed event. Accordingly, in (1), it is asserted that Fred read the book at some time $t$ in the past and it is presupposed that Fred read the book at some $t^{\prime}$ preceding $t$.

Let us return to the issues that repetitive adverbials raise. First, the interpretation of repetitives is not trivial. We note some issues below. A simple definition reflecting the characterization above, is given by Beck (2005), where $<$ indicates temporal precedence:

$$
\begin{aligned}
\llbracket \text { again } \rrbracket\left(P_{\langle i, t\rangle}\right)(e) & =1 \text { iff } P(e) \& \exists e^{\prime}\left[e^{\prime}<e \& P\left(e^{\prime}\right)\right] \\
& =0 \text { iff } \neg P(e) \& \exists e^{\prime}\left[e^{\prime}<e \& P\left(e^{\prime}\right)\right] \\
& \text { undefined otherwise }
\end{aligned}
$$

(Beck 2005) 
This definition raises some problems. For example, consider the predicate play. Intransitive event descriptions such as Fred played are homogeneous; an event of Fred playing can contain another event of Fred playing. If Fred plays from 10:00 to 4:00, then he also plays in the interval from 10:00 to 12:00. This means that if Fred plays from 10:00 to 4:00, we could utter at 1:00 that Fred plays again, even though the earlier stretch of time forms part of the larger event that is still in progress.

This situation is something that the definition of von Stechow (1996) rules out. His definition is given below.

(3) Let $P$ be a property of eventualities and let e be an eventuality.

$\llbracket$ again $\rrbracket(P)(e)$ is defined only if $\exists e^{\prime}\left[\llbracket \operatorname{MAX} \rrbracket(P)\left(e^{\prime}\right)=1 \& e^{\prime}<e\right]$

Where defined, again $\rrbracket(P)(e)=1$ iff $P(e)=1$

MAX is a symbol of type $\langle\langle s, t\rangle,\langle s, t\rangle\rangle . \llbracket \operatorname{MAX} \rrbracket(P)(e)=1$ iff $P(e)$ and there is no $e^{\prime}$ such that $e$ is a proper part of $e^{\prime}$ and $P\left(e^{\prime}\right)=1$

(von Stechow 1996)

Note that this definition requires presupposed events to be maximal, so this definition does not allow again to be used at 1:00 in the situation above. Since the presupposed event must be maximal, maximality must be interpreted with respect to the particular situation under discussion and not in general. This is because a number of event descriptions, specifically atelic descriptions, can never be maximal (it is always possible, in theory, to continue the event further). Yet atelic event descriptions can appear with again, naturally.

(4) Fred played again.

Before proceeding to the second issue, let us point out that Klein (2001) notes some other problems. First, (5) not only requires that we are on Axalp at an earlier time $t^{\prime}$. It is also odd, as Klein observes, if the asserted event is not preceded by an interval at which we are not on the Axalp. This requirement does not follow from either of the definitions above.

(5) Im folgenden Herbst waren sie wieder auf der Axalp. in.the next fall were they again on the Axalp 'Next fall, they were on Axalp again.'

(German; Klein 2001)

In addition, there are atemporal situations which can be modified by again. This fact is unexpected if the definition of von Stechow (1996) is adopted. 
(6) Neunzehn ist wieder eine Primzahl.

nineteen is again a prime.number

'Nineteen is a prime number again.'

(German; Klein 2001)

According to Klein (2001), (6) is felicitous in different conditions. If the main stress is on Primzahl, then it is natural in a sequence that elaborates which numbers are prime numbers (e.g., ' 17 is a prime number, 18 is not a prime, 19 is a prime number again'). With stress on wieder, a natural context is a random list of numbers. Given the list 14, 16, 23, 19, one may say ' 23 is a prime number, and 19 is a prime number again'. In contrast with the first scenario, here - as Klein observes - the relevant fact is that it has been mentioned before that some number is prime. Let us note that perhaps a third situation also makes (6) felicitous. There are various methods of verifying if a number is prime. Imagine that the first method tell us that 19 is prime. The second method tells us, again, that 19 is prime. This makes the description felicitous. The important fact here is that mere earlier existence of the state of being a prime number is not sufficient. Rather, all three scenarios described for (6) require some previous observation or statement of the fact that some number is prime. A definition of again should address all of these concerns and more; this issue is addressed in section 4 .

Second, the difference between repetitive and restitutive has been addressed in various places (von Stechow 1996; Fabricius-Hansen 2001; PatelGrosz \& Beck 2014, among many others). The two interpretations are illustrated below. ${ }^{1}$ Note that the repetitive requires that the presupposed event be the same type as the asserted event. With the restitutive interpretation, the earlier event is the same type as the result state of the asserted event.

(7) Fred closed the door again.

a. Presupposed: Fred closed the door at some earlier time $t^{\prime}$.

(repetitive)

b. Presupposed: The door was closed at some earlier time $t^{\prime}$.

(restitutive)

One issue in connection with the two interpretations is the source of the variability in meaning. Von Stechow (1996) argues that it is a syntactic distinction, due to different structural positions of again. Fabricius-Hansen (2001) argues that there are two distinct lexical entries of again, corresponding to the two interpretations. As Patel-Grosz and Beck (2014) show,

${ }^{1}$ Some authors, including Lechner et al. (2015) argue that there are more interpretations available; I am ignoring those readings here. 
it appears that both accounts are right. An account of Kutchi Gujarati pacho requires both a lexical ambiguity and a structural ambiguity account.

Third, while again and German wieder, as discussed above, are independent adverbs, there are affixed or clitic-like repetitive adverbs as well. Some of these are shown below.

(8) a. Fred rebuilt the house.

b. Ha ributtato via il latte. has re.thrown away the milk 'He has thrown away the milk.'

(Italian; Cardinaletti 2003)

c. Jean refermera la porte.

Jean re.close-will the door

'Jean will close the door.'

(French; Sportiche 2012)

An issue that arises in connection with these elements is morphological. Keyser and Roeper (1992) argue that English re- is a clitic. Cardinaletti argues, in contrast, that Italian $r i$ - is a (syntactically) incorporated adverb rather than a clitic and Sportiche reaches the same conclusion for French re-.

Fourth, repetitives are not uniform with respect to the argument structure of the predicate they combine with. Consider English re- and Italian $r i$. As Keyser and Roper (1992) note, the distribution of re- is restricted. It cannot appear with a variety of verbs, which include particle verbs. No such restriction holds for Italian ri-, thus (8b) is grammatical. In addition, English re-, unlike again, requires an underlying object (in addition to imposing other constraints on the predicate it appears with):

(9) a. *Fred resmoked.

b. Fred smoked again.

Fifth, a number of syntactic issues arise as well. They include the question of word order for non-bound adverbials, the scope of repetitives and indefinite expressions (10) and the scope of repetitives and adverbs (11).

Indefinite objects scope above restitutive again, but they can scope below repetitive again. Such a state of affairs is compatible with a syntactic treatment of the restitutive-repetitive ambiguity (von Stechow 1996), but it is unexpected for a lexical treatment (Fabricius-Hansen 2001). The following examples are adapted from Lechner et al. (2015). 
(10) a. Indefinite object and restitutive again

i. John is in a room with two windows. One window is open and the other one is closed. John opens the closed window.

ii. "John opened a window again.

iii. Only a window > again: The window that John opened had been open before.

b. Indefinite object and repetitive again

i. John is in a room with two windows. Both are closed. John opens one of the windows. It is still too warm, so he opens the second window, too.

ii. John opened a window again.

iii. Available again $>$ a window: John had opened some window before.

(Lechner et al. 2015)

In (11), again must scope over the agent-oriented carefully, since postverbal adverbials show inverse scope. This forces a high attachment site for the repetitive, (VoiceP, above vP, for Lechner et al. 2015), which correlates with the unavailability of the restitutive interpretation. Similarly, punctual temporal adverbials have a high attachment site, as they adjoin to vP. Restitutives cannot outscope such adverbials either:

(11) a. John opened the window carefully again.

i. John opened the window carefully previously.

ii. *The window was open carefully previously.

(repetitive)

(restitutive)

b. John opened the window on Wednesday again.

i. John opened the window on Wednesday previously. (repetitive)

ii. *The window open on Wednesday previously. (restitutive)

(see Lechner et al. 2015)

The scope facts show that restitutive again must be attached below vP and VoiceP, unlike repetitive adverbials, supporting a structural account of the repetitive-restitutive ambiguity.

The remainder of the paper will consider a variety of repetitive adverbials in Hungarian, listed in (12a). Additional adverbials occasionally considered include még egyszer 'once again, since that adverbial also presupposes an earlier occurrence of the event. Finally, we will also consider vissza 'back'. This adverbial also presupposes an earlier event, but the event must be "counterdirectional" to the asserted event; such an entry lies behind the lexical ambiguity approach of Fabricius-Hansen (2001). Some of the repetitives have a reduplicated form; these are shown in (12e). Grammatical reduplicated forms behave like their non-reduplicated counterparts. 
(12) a. megint, ismét, újra, újfent 'again'

b. még egyszer 'once more'

c. vissza

d. i. megint és megint 'again and again', ?? ismét és ismét, újra és újra, ?*újfent és újfent

ii. ?'még egyszer és még egyszer

iii. *még mindig és még mindig

iv. vissza és vissza

The main claim of the paper is that there is considerable variation in the behavior of repetitive adverbials, most notably in the availability of different readings. There is no obvious connection between the possible interpretations and other properties of the repetitives, including etymology or transparent morphological complexity. It appears necessary, therefore, to stipulate these properties for the individual adverbials.

The remainder of the paper is structured as follows. Section 2 discusses the basic syntactic properties (word order facts and scope). The section also contains a discussion of repetitive and restitutive readings as well as possible interpretations in causative structures. It is argued that the different interpretations are due to structural ambiguity along the lines of von Stechow (1996). The section also contains a more detailed discussion of uijra 'again', the repetitive adverbial which can appear either as an independent adverbial or as a verbal modifier. It is proposed that these two types of újra must be encoded as distinct lexical entries. Section 3 discusses resultative structures in more detail. Section 4 briefly addresses the interpretation of repetitives and section 5 discusses the morphological makeup of the adverbials. Section 6 concludes the paper.

\section{Syntactic properties}

This section considers the basic syntactic properties of repetitives. A general conclusion is that the distribution of repetitives varies. It appears that this variation must be stipulated independently; it does not seem to correlate with other properties of these modifiers.

\subsection{Word order}

The majority of the adverbials listed in (12a) can only appear as independent modifiers. Some of those can also appear as verbal modifiers (igekötô). 
Verbal modifiers in Hungarian generally immediately precede the verb ${ }^{2}$ and they form an intonational unit with the verb; in these cases, the verb bears no stress. Verbal modifiers are spelled as one word with the verb when the modifier is preverbal. In spite of this spelling convention, the verbal modifier and the following verb are spelled as independent words for transparency. Example (13) shows that újra 'again' and vissza 'back' can function as verbal modifiers; $k i$ 'out' is also a verbal modifier. 'shows the position of stress.

(13) a. Feri'újra olvasta a könyvet.

Feri again read the book-ACC

'Feri read the book again.'

b. Feri vissza adta a könyvet

Feri back gave the book-ACC

'Feri returned the book.'

c. Feri'ki olvasta a könyvet.

Feri out read the book

'Feri read the book (to the end).'

The verbal modifier újra also patterns with other verbal modifiers in that it does not permit bare objects. Once again, ' indicates stress. We return to properties of the verbal modifier újra below.

(14) a. Feri'újra olvasott egy könyvet/*könyvet.

Feri again read a book-ACC/book-ACC

'Feri read a book again.'

(verbal modifier)

b. Feri' újra 'olvasott egy könyvet/könyvet.

Feri again read a book-ACC/book-ACC

'Feri read a book again.'

(non-verbal modifier)

In general, repetitives can occur in a variety of positions. Some of these are peripheral, as shown below. A number of repetitives can appear on the left periphery, forming a separate intonational unit. The relevant event which must have occurred previously is not the event described in the sentence. Rather, repetition concerns the speech act; it was stated previously that he never said no.

${ }^{2}$ Unless the sentence contains negation, (non-predicate) focus, or is imperative; in these cases, the verbal modifier is postverbal. 
(15) Once more/Again/Once again, he never said no.

Even though in English a number of repetitives permit the speech actrelated use, it is only available for még egyszer in Hungarian. All other repetitives are ungrammatical (only megint is shown):

(16) Még egyszer, $/{ }^{*}$ Megint, soha nem mondott nemet.

yet once/again never not said no-ACC

'Again, he never said no.'

Before proceeding to a more detailed discussion of the distribution of repetitives, let us summarize the basics of Hungarian clause structure (see É. Kiss 2002, among many others). The verb is followed by any number of adjuncts or arguments. The preverbal elements include - from left to right - topics, quantifiers and foci or verbal modifiers. Foci and verbal modifiers are immediately preverbal (and in the presence of focus, the verbal modifier follows the verb). The preverbal position corresponds to scope position.

(17) Topic* quantifer* focus/verbal modifier verb ...

The function of the preverbal elements in (18) is shown by subscripts. The possible surface positions of repetitives are indicated by $\bullet$.

(18) Feri $_{\text {Topic }} \bullet$ mindenkit $_{\text {Quantifer }} \bullet$ KÁVÉRA ${ }_{\text {Focus }}$ hívott meg $_{\text {Verbal modifier }} \bullet$ Feri everyone-ACC coffee-onto invited perfective

'Feri invited everybody to COFFEE.'

Recall that the repetitives considered here are the following: megint, ismét, újra, újfent, még egyszer. Repetitives cannot precede topics or occur between preverbal topics. They can freely appear in the other positions indicated by bullets (I assume that these positions are adjoined to the quantifier and focus projections). Postverbal positions are dispreferred and somewhat marked, except for még egyszer 'once more'. Thus, even though még egyszer, like other repetitives, presupposes the existence of an earlier event, it is acceptable postverbally (similarly to other multiplicatives).

\subsection{Scope}

Given that preverbal positions in Hungarian correspond to scope, it is expected that the word order of repetitives reflects their scope. Consider (19a). It is predicted that this sentence will only have the first reading; 
that is, the person who closed the door must have closed it previously. This prediction is not borne out; indeed, (19a) is synonymous with (19b).

(19) a. Valaki megint be csukta az ajtót.

someone again in closed the door-ACC

'Someone closed the door again.'

i. There is someone who closed the door and that person has closed the door previously (someone $>$ again).

ii. Someone closed the door and someone (perhaps a different person) has closed the door previously (again > someone).

b. Megint be csukta az ajtót valaki.

again in closed the door-ACC someone

'Someone closed the door again.'

The scope between universal quantifiers and repetitives is expected to be surface scope only. This prediction is borne out. Given the second position of megint in (20), it is expected that the set of individuals who wrote their homework must be the same. This is, however, not true. Consider a class that is not too popular; it is always a different set of students who show up for class. If every student present on Monday wrote their homework, and every student present on Wednesday did so as well, then this situation can only be described with megint 1 , as expected.

(20) $\left(\right.$ Megint $\left._{1}\right)$ mindenki $\left(\right.$ megint $\left._{2}\right)$ meg írta a házit.

again everyone again perfective wrote the home.work-ACC

'Everyone wrote the homework again.'

a. Everyone wrote the homework and the same set of people has written the homework previously (everyone $>$ again).

b. Everyone wrote the homework and everyone (perhaps a different set of people) has written the homework previously (again $>$ everyone).

Other repetitives behave similarly to megint.

\subsection{More on possible positions}

The surface positions for repetitive adverbs are thus largely uniform. Before proceeding to a discussion of repetitive and restitutive interpretation, we will briefly address the scope with respect to agent-oriented manner and temporal adverbials. On the structural account, restitutive interpretation requires low scope for repetitives, below vP. Thus, if megint scopes above a high adverbial, it is predicted that only the repetitive interpretation will be available. 


\subsubsection{Repetitive and restitutive readings}

The predictions concerning the repetitive-restitutive ambiguity are borne out. For a repetitive that precedes the high adverbial, only a repetitive interpretation is available, and if the repetitive follows the high adverb, a restitutive reading is also possible.

(21) a. Feri (megint) óvatosan (megint) ki nyitotta az ablakot.

Feri again carefully again out opened the window-ACC

'Feri opened the window carefully again.'

b. Feri (*megint) szerdán (megint) ki nyitotta az ablakot.

Feri again Wednesday-on again out opened the window-ACC

'Feri opened the window again on Wednesday.'

Note, however, that the repetitive cannot precede the temporal adverbial in (21b). This is unexpected, given the assumption in Lechner et al. (2015) that agentive manner adverbials are adjoined to VoiceP and temporals to $\mathrm{vP}$, with Voice dominating $\mathrm{vP}:^{3}$

(22) [[voiceP [ [ veP open the window] on a Wednesday]] carefully]

Word order facts are consistent with the repetitive pattern shown in (21a) and (21b); the temporal modifier must precede the manner adverbial:

(23) Feri (szerdán) óvatosan (*szerdán) ki nyitotta az ablakot.

Feri Wednesday-on carefully Wednesday-on out opened the window-ACC

'Feri opened the window carefully on Wednesday.'

As expected, temporal modifiers must appear higher than universal quantifiers, since the latter can be preceded by repetitives. Agentive manner adverbials, in contrast, must follow quantifiers: ${ }^{4}$

(24) a. Feri (szerdán) mindenkit (*szerdán) meg hívott.

Feri Wednesday-on everyone-ACC Wednesday-on perfective invited

'Feri invited everyone on Wednesday.'

3 The examples in Lechner et al. (2015) contain on a Wednesday; however, in their characterization, they refer to temporal adverbials. This leads to the expectation that their characterization extends to all punctual temporal modifiers.

${ }^{4}$ It is possible for óvatosan 'carefully' to precede the quantifier. In this case, however, it is a sentential rather than a straightforward manner adverbial. 
b. Feri (*óvatosan) mindent (óvatosan) el rakott.

Feri carefully everything-ACC carefully away put

'Feri put everything away carefully.'

Summarizing the facts so far, we arrive at the following structure, where shows the possible positions of repetitive adverbials. Once again, note that the relative position of agentive manner adverbials and temporal modifiers differs from that assumed by Lechner et al. (2015).

$$
\begin{array}{r}
{[\text { TopicP Topic* Wednesday } \bullet[\text { QuantifierP quantifer* } \bullet \text { manner } \bullet} \\
[\text { FocusP focus } / \text { verbal modifier verb ... }]]]
\end{array}
$$

It was asserted that if the repetitive follows agentive manner adverbials, then either a repetitive or a restitutive interpretation is possible. This is so because in the majority of cases, the repetitive reading entails the restitutive interpretation. Thus, if the restitutive interpretation is possible, then generally a repetitive interpretation is available as well. The question is therefore whether both interpretations are possible in the post-manner adverbial position, or only a restitutive reading is available.

Lechner et al. (2015) note that with non-monotonic quantifiers, it is possible that no entailment holds between the two readings. It is possible to construct a scenario where the repetitive reading holds, but the restitutive one is false. Consider the following scenario. Two people enter a room with a single window. The window is closed. $A$ opens the window carefully. The draft closes it, and $B$ opens the window carefully again. The draft closes the window once more, and $A$ opens it carefully yet again. In this case, the description in (26) is only true under a repetitive interpretation.

(26) Pontosan egy ember nyitotta ki óvatosan megint az ablakot.

exactly one person opened out carefully again the window-ACC

'Exactly one person opened the window again carefully.'

a. Restitutive: There is exactly one person such that there was an open window, it was closed, and that person opened the window again (false; there are two such people).

b. Repetitive: There is exactly one person such that that person opened a window, it was closed, and then he opened it again (true; only $A$ opened the window twice).

Informants judged the example to be true in the situation, indicating that repetitive interpretation is also available in the position following the manner adverbial. This is expected, since if the projection c-commanded by the 
adverbial is at least a $\mathrm{vP}$, then repetitive readings, where the adverbial scopes over the $\mathrm{vP}$, should be possible: ${ }^{5}$

(27) manner [.vP megint [.vP verbal modifier verb ...]]

As for the restitutive interpretation, I assume that the adverbial is generated lower, adjoined to VP. The repetitive subsequently moves to its surface position (possibly adjoining to $\mathrm{vP}$ ), but undergoes reconstruction. Given the movement of restitutive repetitives, there is no word order difference between repetitive adverbials with repetitive or restitutive interpretation.

Another kind of interaction to consider is the scope of indefinite objects and restitutive repetititives. Recall that in English, the indefinite must scope over the repetitive in the example repeated below.

(28) John opened a window again. (*again $>$ a window)

The same facts hold for Hungarian. In the situation where one window is open, and Feri opens another one, the following description is not felicitous:

(29) Feri megint/újra ki nyitott egy ablakot.

Feri again/again out opened a window-ACC

'Feri opened a window again.' (*again $>$ a window)

Thus, the position of restitutive repetitives is lower than the lowest scope position of indefinites. Scope facts were discussed in more detail in section 2.2.

So far, the repetitive - restitutive interpretation is as expected, and it behaves as predicted by the structural ambiguity account of von Stechow (1996). The remainder of this section considers these readings and some additional ones for all repetitive adverbials.

First, note that some, but not all repetitives are decompositional. A decompositional adverb can modify a subconstituent of the vP. A structural account of the restitutive interpretation maintains that the repetitive modifies the VP in this case. ${ }^{6}$ As in (30), megint and újra permit restitu-

${ }^{5}$ The relevant facts still hold if foci and verbal modifiers appear in a projection that dominates $\mathrm{vP}$.

${ }^{6}$ In addition to some repetitives, majdnem 'almost' and its English equivalent are also decompositional. 
tive interpretation, but the other repetitives do not. Given the situation sketched, only a restitutive reading is possible. ${ }^{7}$

(30) The window was closed when Feri walked in. He opened it, but then he realized that it was too cold outside. So he closed the window again.

a. Feri megint/újra be csukta az ablakot.

Feri again/again in closed the window-ACC

'Feri closed the window again.'

b. *Feri újfent/ismét/még egyszer be csukta az ablakot.

Feri again/again/yet once in closed the window-ACC

'Feri closed the window again/once more.'

As expected, a repetitive reading is possible for all repetitive adverbials:

(31) Feri closed the window. Mari opened it, but Feri decided that it was too cold in the room. He walked to the window and closed it again.

a. Feri megint/újra be csukta az ablakot.

Feri again/again in closed the window-ACC

'Feri closed the window again.'

b. Feri újfent/ismét/még egyszer be csukta az ablakot.

Feri again/again/yet once in closed the window-ACC

'Feri closed the window again/once more.'

The fact that restitutive interpretation is possible is somewhat controversial. Horvath and Siloni (2011) note that no restitutive reading is available for megint for the speakers consulted. This observation is in conflict with the judgments obtained here; restitutive meaning is easily available for the speakers surveyed for this paper. ${ }^{8}$

In addition, Horvath and Siloni (2011, footnote 42) argue that the repetitive-restitutive ambiguity with again cannot be structural ambiguity; they mention the lexical ambiguity approach of Fabricius-Hansen (2001) as a possible alternative. Now, they also assert that restitutive interpretation is sometimes available in Hungarian, even though not as freely as in English. However, if restitutive interpretation is ever available, and it requires a different kind of entry for the Hungarian repetitive, then the prediction seems to be that it is more widely available. The reason why restitutive is not available for some speakers of Hungarian remains elusive.

${ }^{7}$ Horvath and Siloni (2011) note that for some speakers, restitutive interpretation was not available with either megint or újra. For the speakers consulted for this paper, they accepted the restitutive reading for both of these adverbials.

${ }^{8}$ See also Bartos (2011) on Horvath \& Siloni (2011). 


\subsubsection{Causative structures}

Horvath and Siloni (2011) argue that Hungarian causatives are syntactically simple. They offer a variety of evidence, including evidence from the scope of negation, VP-ellipsis, binding facts and the interpretation of agent-oriented adverbials, for the claim that causatives are simple in syntax, having been derived in the lexicon.

(32) Feri ki számoltatta az adót a könyvelóvel.

Feri out calculate.CAUS.PAST.3SG the tax-ACC the accountant-with

'Feri had the accountant calculate the tax.'

As an illustration, consider the negation facts. Negation, which precedes the verb, must scope over the entire complex event; scope over the caused subevent is impossible:

(33) Nem énekeltettem a gyerekeket.

not sing.CAUS.PAST.1SG the kids-ACC

'I didn't make the kids sing.' (unavailable: 'I made the kids not sing')

(Horvath \& Siloni 2011, (12))

Even if a restitutive interpretation is unavailable, as claimed by Horvath and Siloni (2011), repetitive structures are expected to allow distinct repetitive readings.

(34) János íratott megint egy levelet a titkárnővel.

Janos write.CAUS.PAST.3SG again a letter-ACC the secretary-with

'János made the secretary write a letter again.'

a. János has done that before.

b. *The secretary has done that before.

(Horvath \& Siloni 2011, (75))

The second reading is consistent with the following situation. The secretary writes a letter, which she decides to trash. János then tells her to write another letter. According to Horvath and Siloni, this reading is not available for $\left(34\right.$, independently of the position of megint. ${ }^{9}$

${ }^{9}$ Horvath and Siloni (2011) note that the lower repetitive reading is available in some cases, such as the one reproduced below:

(i) a. The students read out their essays in class last Tuesday.

b. Másnap új tanár tartotta az órát, és az megint next.day new teacher old.PAST.DEF the class-ACC and that.one again 
The speakers consulted, however, had no trouble accepting the lower repetitive reading for a variant of (34) as well for a number of causatives of distinct predicates (unaccusative, unergative, transitive, ditransitive predicates as well as predicates containing adjuncts). Informants generally dispreferred postverbal repetitives, in contrast with the characterization of Horvath \& Siloni (2011); (34) was judged to have the low reading with preverbal megint.

If the lower repetitive reading is available, then two questions arise. First, why is the lower repetitive available, while the negation facts indicate a single predicate? Second, why do speakers differ in whether they permit the lower repetitive reading?

For the first question, I tentatively suggest that negation (as well as VP-ellipsis, condition B violations and agent-oriented adverbials) require a larger chunk of structure than repetitives. VP-ellipsis, for example, targets constituents of a specific type (larger than VP, with the specific type not discussed here). Thus, if the category of the lower subevent is distinct from what is targeted by ellipsis, then eliding the lower subevent only will be impossible. This approach invokes restructuring, where languages with restructuring permit constituents of a smaller size than those that lack the process. Repetitives, in contrast, can modify a range of constituents, including the lower subevent.

As for the second question, I suggest that speakers of Hungarian may differ in the range of constituents repetitives can modify. For restrictive speakers of the type described by Horvath \& Siloni (2011), they may require repetitive adverbials to modify a VoiceP or a similar verbal projection which is only projected by the causer subevent. Speakers who permit restitutive and lower repetitive reading have no such constraint.

While megint was judged acceptable when modifying lower repetitive subverts, other repetitive adverbials (újra, ismét, úffent and még egyszer show variable behavior. The pattern of these adverbials is not uniform and acceptability appears to vary (at least) with the argument structure of the description of the caused subevent. At this point, no clear generalizations

felolvastatta velük a fogalmazásukat.

up.READ.CAUS.PAST.DEF insert.3PL the composition.POSA.3PL-ACC

'The next day a new teacher taught the class, and he made them read out their essays again.' (possible reading: 'The students did it again.')

(Horvath \& Siloni 2011, footnote 42)

Once again, it can be pointed out that if the variation in interpretation stems from lexical ambiguity, then it is not clear why the lower reading is possible in the example above, but not in (34). 
emerge with respect to the restrictions imposed by the adverbials. It is clear, however, that the behavior of repetitive adverbials is not uniform and it is likely that some of the differences must be lexically determined.

\subsubsection{Another decompositional adverb}

Repetitives which can modify a smaller constituent (whether permitting a lower repetitive or a restitutive interpretation) are decompositional; they help in decomposing the predicate. Another decompositional adverb is majdnem 'almost', similarly to its counterparts.

(35) Feri majdnem be csukta az ajtót.

Feri almost in close.PAST.3SG the door-ACC

'Feri almost closed the door.'

Majdnem 'almost' can modify the larger predicate; in this case, Feri did not even start closing the door. Or it can modify the result; in this case Feri did something, and that was almost closing the door. This variation in interpretation parallels repetitives, where it is either the result (restitutive) or the entire event (repetitive) that is repeated.

The distribution of majdnem is similar to that of repetitives, but their interpretation differs. While it can precede quantifiers such as mindenki 'everyone', in that case it modifies the quantifier:

(36) Majdnem mindenki Quantifier be csukta az ajtót.

almost everyone in closed the door-ACC

'Almost everyone closed the door.'

If majdnem precedes focus, then as expected, it scopes over focus:

(37) Majdnem FerIFocus csukta be az ajtót.

almost Feri closed in the door-ACC

'It was almost Feri that came.'

The familiar interpretation arises when majdnem does not precede either focus or quantifiers, as in the example below. With telic descriptions, the interpretation is ambiguous, as it is in other languages as well. Majdnem scopes either over the entire event, or over the result only. With atelic examples, only the interpretation parallel to (i) below is available. 
(38) Feri majdnem be csukta

az ajtót.

Feri almost in close.PAST.3SG the door-ACC

'Feri almost closed the door.'

((i) Feri did not close the door; (ii) Feri closed the door, but not completely.)

Let us consider how majdnem behaves in the causative structures discussed above. Recall from the previous section that for the informants consulted, megint 'again' has two possible repetitive interpretations: either the caused subevent or the causing event may be repeated. Since the lower predicate is telic, a third reading is also expected.

(39) Feri a könyvelövel majdnem/megint ki számoltatta az adót.

Feri the accountant-with almost/again out calculate.CAUS.PAST.3SG the tax-ACC 'Feri almost had the accountant calculate the tax.'/'Feri had the accountant calculate the tax again.'

a. Feri almost had the accountant calculate the tax (high repetitive).

b. Feri did something, which almost caused the accountant calculate the tax (low repetitive).

c. Feri had the accountant do something; this was almost calculating the tax (going through most of the steps towards calculating the tax) (result).

While the lowest reading is somewhat marginal, both repetitive readings are available. This is consistent with the observations about the repetitive megint and is at odds with the characterization in Horvath \& Siloni (2011). Once again, given the description of Horvath and Siloni, it appears that Hungarian is not uniform with respect to the decompositional readings it permits.

\subsection{Verbal modifiers and independent adverbials}

This section considers the properties of the two adverbials which can optionally appear as verbal modifiers: újra and vissza 'again'. It is shown that their behavior is radically distinct (for example, the distribution of verbal modifier újra is more restricted that that of its non-verbal counterpart, while the opposite is true for vissza). The restrictions on verbal modifier újra are thus not directly due to its verbal modifier nature. I assume instead, that the restrictions must be stipulated independently, for a lexical entry of verbal modifier újra. 


\subsection{1. Újra}

The repetitives discussed above do not include verbal modifier újra. Recall that újra can appear either as an independent adverbial or as a verbal modifier. The verbal modifier repetitive appears similar to English re-, illustrated below. It will be shown that in spite of initial appearances, $r e$ - and 'ujra are significantly distinct (the apostrophe before újra is an indication that this adverbial bears main stress in neutral sentences, by virtue of being in the preverbal verbal modifier position).

(40) Fred rewrote his homework

There is crosslinguistic variation in how incorporated repetitive adverbials work. Recall from section 1 that English re- imposes a number of restrictions. These include restrictions on argument structure. Some incorporated repetitives, such as Greek ksana- (Lechner et al. 2015), Italian ri- (Cardinaletti 2003) and French re- (Sportiche 2012) impose no such restrictions. In addition, indefinites always outscope English re-. This does not extend to incorporated ksana- either. Finally, re- obligatorily scopes below aspectual adverbs, while this does not extend to ksana- (Williams 2011; Lechner et al. 2015). The aspectual adverb scope facts are shown below.

(41) a. John repolluted the river completely.

(completely $>r e-,{ }^{*} r e->$ completely; the prior pollution was not necessarily complete)

b. O Janis ksanamoline to potami oloklirotika.

the John repolluted the river completely

'John repolluted the river completely.'

$(\text { completely }>\text { re-, re- }>\text { completely })^{10}$

(Lechner et al. 2015, 18)

The scope facts follow from the fact that English re- has an obligatorily narrow scope since it is merged low. Lechner et al. (2015) argue for Greek $k s a n a$ specifically that it can be merged in a variety of positions, incorporated into the verb and moves to $\mathrm{T}$ along with it, and the complex can subsequently reconstruct. The argument structure restriction for re- follows from its selection requirements.

With this background, let us consider újra. Verbal modifier újra appears to pattern with re-: it cannot appear with ditransitive predicates, particles (which function as verbal modifiers), resultatives and causatives

${ }^{10}$ It is not clear how, if the second scope is possible, the wide scope of the adverbial can be verified. Williams (2011) claims that in Greek, the prior pollution must also have been complete. 
of intransitive predicates, as shown below. The English examples are based on Keyser \& Roeper (1992). ${ }^{11}$

(42) a. *Feri' újra adott Marinak pénzt.

Feri again gave Mari-DAT money

'Feri gave Mari money again.'/*'Feri re-gave Mari money.'

b. *Feri újra adta magát fel.

Feri again gave himself up

'Feri gave himself up again.'/*'Feri re-gave himself up.'

c. *Feri újra törte félbe az ágat.

Feri again broke half-into the branch-ACC

'Feri broke the branch in half again.'/*'Feri re-broke the branch in half.'

d. *Feri' újra idegesítette Marit.

Feri again nervous.caus Mari-ACC

'Feri made Mari nervous again.' (cf. *'Feri re-worried Mari.')

Verbal modifier 'újra is also similar to re- in requiring an underlying object.

(43) *Feri 'újra nevetett/dohányzott.

Feri again smiled/smoked

'Feri smiled/smoked again.'/*'Feri re-smiled/re-smoked.'

The predicate modified also has some aspectual restrictions with both repetitives. 'Ujra cannot appear with achievements. At first sight, it appears that only telic predicates can be modified by both 'újra and re-, as in (45):

(44) Feri'újra rugta a falat.

Feri again kicked the wall-ACC

'Feri kicked the wall again.'/*'Feri re-kicked the wall.'

(45) a. *Feri'újra tolta a kocsit.

Feri again pushed the car-ACC

'Feri pushed the car again.'/**Feri re-pushed the car.'

b. Feri újra melegítette a kávét.

Feri again warmed the coffee-ACC

'Feri warmed the coffee again.'/'Feri re-heated the coffee.'

${ }^{11}$ Lechner et al. (2015) note that re- does not appear with unaffected objects. This is not entirely accurate, since Fred re-watched all previous episodes of "Homeland" is grammatical, as is the Hungarian equivalent. 
c. Feri'újra olvasta a könyvet.

Feri again read the book-ACC

'Feri read the book again.' /'Feri re-read the book.'

However, the telicity generalization is not accurate. While all three predicates in (45) can be telic in English, the predicates without újra are atelic in the Hungarian examples in (45a) and (45c). The requirement for Hungarian verbal modifier 'újra appears to be the presence of a closed eventhomomorphic element. ${ }^{12}$ In (45b) the (event-homomorphic) temperature scale is closed, since the event ends when the appropriate temperature for the coffee is reached. In (45c) the scale is provided by the direct object; reading progresses along the book.

Incidentally, the closed event-homomorphic requirement also rules out the examples shown in (42). ${ }^{13}$ Datives are possible with újra (re-permits only a single argument). Particles remain ungrammatical; this restriction does not obviously follow from the event-homomorphic requirement (it is suggested to follow from the requirement of both elements to appear as resultatives).

(46) a. Feri'újra melegítette Marinak a kávét.

Feri again warmed Mari-DAT the coffee-ACC

'Feri re-heated the coffee for Mari.'

b. *Feri újra olvasta el a könyvet.

Feri again read away the book-ACC

'Feri re-read the book.'

Resultatives also behave differently with the two repetitives. While both re- and 'ujra permit some resultatives and disallow others, the range of re-

12 This seems to a necessary, but not a sufficient condition, as the following examples are ill-formed, in spite of having a closed event-homomorphic argument:

(i) a. *Feri 'újra súrolta a padlót.

Feri again scrubbed the floor-ACC

'Feri scrubbed the floor again.'

b. ${ }^{\%}$ Feri'újra hútötte a bort.

Feri again cooled the wine-ACC

'Feri cooled the wine again.' (cf. melegit 'heat' is fully grammatical with'újra)

13 The examples in (42) do not involve event-homomorphic elements. Thus, it is expected that (42a) will remain ungrammatical, for example, even with a definite object. For some speakers, küld 'send' can appear with a definite object and verbal modifier újra. This contradicts the event-homomorphic generalization. 
sultatives differs for the two repetitives. Both resultatives are grammatical in (59a), but the resultative red is fully acceptable only in English in (59b). Distinct types of resultatives are discussed in more detail in section 3 .

(47) a. Feri újra melegítette a kávét 70 fokra.

Feri again heated the coffee-ACC 70 degree-onto

'Feri reheated the coffee to 70 degrees.'

b. ?Feri'újra festette az ajtót pirosra.

Feri again painted the door-ACC red-onto

'Feri repainted the door red.'

Let us consider scope facts. Indefinite objects obligatorily scope above újra, making a once-only predicate infelicitous, as it is in English as well. Modification by teljesen 'completely' is inconclusive. Even though it is not presupposed that the prior event was also complete, note that in absence of ujra, teljesen is unacceptable, as in (48d). Thus, presumably teljesen cannot modify the lower predicate which excludes the repetitive. However, the lack of completeness for the prior event is similar to re-, which scopes below the aspectual adverb.

(48) a. "Feri 'újra evett egy szendvicset.

Feri again ate a sandwich-ACC

'Feri ate a sandwich again.'

b. Feri teljesen 'újra írta a levelet.

Feri completely again wrote the letter-ACC

'Feri rewrote the letter completely.'

c. Feri újra írta a levelet teljesen.

Feri again wrote the letter-ACC completely

'Feri rewrote the letter completely.'

d. *Feri teljesen írta a levelet.

Feri completely wrote the letter-ACC

'Feri wrote the letter completely.'

The low merge position for'újra also predicts that it only permits restitutive interpretation. Recall from section 2.3.1 that non-monotonic quantifiers can identify repetitive interpretation, excluding restitutives. Consider the following scenario. There is a letter that needs to be worded carefully. 
Person $A$ writes a draft. $B$ rewrites the draft, which is subsequently revised by $A$ again. ${ }^{14}$

(49) Pontosan egy ember írta újra a levelet.

exactly one person wrote again the letter-ACC

'Exactly one person rewrote the letter.'

a. Restitutive: There is exactly one person such that that person rewrote an earlier (draft of) the letter (false; there are two such people).

b. Repetitive: There is exactly one person such that that person wrote the letter earlier and rewrote the letter (true).

For the speakers consulted, example (49) is true in the situation sketched, ${ }^{15}$ indicating that repetitive readings are available. A low, restitutive reading is also expected, since the argument structure restriction on 'újra forces a low merge position. Restitutive interpretation is available; in the following example, Feri does not need to have written the letter previously.

(50) Feri'újra írta a levelet.

Feri again wrote the letter-ACC

'Feri rewrote the letter.'

In sum, verbal modifier 'újra is significantly different from English re- in that the former requires the presence of a closed event-homomorphic element. At the same time, it is also distinct from a number of incorporated repetitives: Greek ksana, French re- and Italian ri- impose no such restrictions. The argument structure restriction suggests a low merge position. In addition, 'újra cannot cooccur with particles; this fact may be explained by cooccurrence restrictions which require 'újra and other particles to occupy the same position. Resultatives vary in whether they can occur with verbal modifier 'újra; resultatives are addressed in more detail in section 3.

14 The repetitive is postverbal because the non-monotonic quantifier phrase must be focused, so all verbal modifiers become postverbal.

15 Though it is not true for all speakers; for these speakers, only a restitutive interpretation is available. Note that the repetitive is postverbal (since the non-monotonic quantifier must immediately precede the verb); this may have an effect on the available interpretations as well. It should also be noted that for some speakers, non-monotonic quantifiers can precede újra, but no other verbal modifiers can do so, as shown below. This may show that újra can form a complex lexical unit with the verb.

(i) Pontosan két ember 'újra olvasta/*'el olvasta az újságot. exactly two person again read/away read the newspaper-ACC 'Exactly two people read the newspaper again/read the newspaper.' 
The low scope of 'újra with respect to indefinites and completely are also consistent with the low merge position.

In the next subsection it is shown that with vissza 'back', another adverbial that has both a verbal modifier and non-verbal modifier form, no similar differences exist between the two forms. It is not the case, then, that the verbal modifier nature of 'ujra is somehow responsible for the closed event-homomorphic requirement. I assume, therefore, that the variation arises from lexical ambiguity; there is an independent lexical entry újra, which is specified as being merged low, imposing the argument structure restriction, and it must appear in the surface verbal modifier position.

It still remains to clarify what the syntactic structure is with verbal modifier 'ujra. Note that the predicate with 'újra is resultative. This is shown by the availability of a restitutive interpretation of the following example. It is possible that the person who rewrote the letter earlier was a person other than Feri, so a restitutive reading must be allowed.

(51) Feri megint újra írta a levelet.

Feri again again wrote the letter-ACC

'Feri wrote the letter again.'

Furthermore, canceling the culmination with 'újra is impossible, so the result must have been achieved:

(52) Feri'újra írta a levelet, \#de nem fejezte be.

Feri again wrote the letter-ACC but not finished in

'Feri rewrote the letter, but he did not finish it.'

Surányi (2009) argues that verbal modifiers in Hungarian are not uniform. They are uniform in their surface position, which is outside of the vP (he tentatively identifies this position as in TP). The resultative interpretation, however, is not characteristic of all verbal modifiers. For those that do have resultative interpretation and are predicative, they move to a PredP position, between $\mathrm{VP}$ and $\mathrm{vP}$, prior to moving to the surface position.

I follow this analysis, with the addition that an argument of 'újra is a verb which has an event-homomorphic argument. The resulting structure is resultative; I assume that the first argument of 'újra is the event-homomorphic element itself. The adverbial then moves to PredP and then to the surface position.

(53) újra [vP v [PredP újra Pred [verb [ResultP újra event-homomorphic argument]]]] 


\subsubsection{The counterdirectional vissza 'back'}

It was noted earlier that the counterdirectional vissza 'back' can also appear as a verbal modifier. It does not always do so, as illustrated in (54). One can ask, based on the discussion of újra above, whether the two types of vissza differ as the two types of újra do.

(54) a. Feri el ment vissza a házba.

Feri away went back the house-into

'Feri went back into the house.' (not verbal modifier)

b. Feri vissza ment a házba.

Feri back went the house-into

'Feri went back into the house.' (verbal modifier)

An obvious difference between újra and vissza is that the former requires reversible predicates:

(55) *Feri vissza ette az almát.

Feri back ate the apple-ACC

*'Feri ate the apple back.'

Note, first of all, that in (54), the counterdirectional functions as a verbal modifier if the particle $e l$ is absent. Only directional particles can function as verbal modifiers and these appear with verbs of motion. With reversible non-verb-of-motion predicates, vissza can only appear as a verbal modifier:

(56) a. Feri oda adta Marinak (*vissza) a pénzt.

Feri there gave Mari-DAT back the money-ACC

'Feri gave the money back to Mari.'

b. Feri vissza adta Marinak a pénzt.

Feri back gave Mari-DAT the money-ACC

'Feri gave the money back to Mari.'

(57) a. Feri fel hívta Marit (*vissza).

Feri up called Mari-ACC back

'Feri called Mari back.'

b. Feri vissza hívta Marit.

Feri back called Mari-ACC

'Feri called Mari back.'

Thus interestingly, non-verbal modifier vissza is subject to more constraints than its verbal modifier counterparts. The only constrain on 
verbal modifier vissza is reversibility of the predicate. No closed eventhomomorphic element is required, as shown by the examples above. Thus, the event-homomorphic argument requirement of verbal modifier 'újra does not follow from its status.

\section{Resultatives}

Resultatives generally permit ambiguous interpretation with the repetitives megint and 'újra, which allow restitutive interpretation. This is true for all three types of resultatives discussed in Washio (1997). The main division is between spurious and non-spurious resultatives. The former permit a paraphrase with an adverbial rather than a resultative, as in (58c). With weak resultatives, shown in (58a), the resultative further specifies a result of the verb and with strong resultatives, as in (58b), the resultative is independent of the verb meaning.

(58) a. Feri megint pirosra festette az ajtót.

Feri again red-onto painted the door-ACC

'Feri painted the door red again.'

i. It happened earlier that Feri painted the door red.

(weak resultative)

ii. The door was red previously.

iii. The door was painted red previously.

b. Feri megint egyenesre kalapálta a vasat.

Feri again straight-onto hammered the iron-ACC

'Feri hammered the iron straight again.'

i. It happened earlier that Feri hammered the iron straight.

ii. The iron was straight previously.

iii. The iron was hammered straight previously.

c. Feri szorosra/szorosan kötötte a cipőfüzőjét.

Feri tight-onto/tight-adverbial tied the shoelace-pose-ACC

'Feri tied his shoelaces tight/tightly.' (spurious resultative)

i. It happened earlier that Feri tied his shoelaces tight.

ii. Feri's shoelaces were tight earlier.

iii. Feri's shoelaces were tied tight earlier.

In theory, three types of interpretations are possible for each resultative type, as shown above. The readings are the repetitive interpretation, a reading where the repetitive scopes over the result predicate only, and a reading where the repetitive scopes over the verb and the result predicate. Indeed, all there interpretations are available for all three resultative types, indicating a parallel treatment. 
It was noted in connection with verbal modifier újra that results are at worst marginal:

(59) a. Feri újra melegítette a kávét 70 fokra.

Feri again heated the coffee-ACC 70 degree-onto

'Feri reheated the coffee to 70 degrees.'

b. 'Feri'újra festette az ajtót pirosra.

Feri again painted the door-ACC red-onto

'Feri repainted the door red.'

This is true for other examples of verbal modifier újra and other verbal modifiers, which are marginal or fully grammatical for speakers, as shown below. This suggests that the repetitive - or other verbal modifiers - and the 'lexical' resultative can form a complex predicate.

(60) a. ${ }^{(?)}$ Feri át/újra festette az ajtót pirosra.

Feri across/again painted the door-ACC red-onto

'Feri painted the door red (again).'

b. ${ }^{(?)}$ Feri ki/újra kalapálta a vasat egyenesre.

Feri out/again hammered the iron-ACC straight-onto

'Feri hammered the iron straight (again).'

c. ${ }^{(?)}$ Feri be/újra kötötte a cipőfüzőjét szorosra.

Feri in/again tied the shoelace-pose-ACC tight-onto

'Feri tied his shoelaces tight (again).'

Surányi (2009) makes a claim that is especially relevant here: he argues that some verbal modifiers which appear to be resultatives are not, in fact, resultatives; in reality, they do not encode a result. According to Surányi (2009), a variety of tests, including the optionality of objects and cancelability of culmination entailment show that several verbal modifiers do not encode a result. Cancelability is illustrated below.

(61) János rá lootte a nyilat a fatörzsre.

Janos onto.it shot the arrow-ACC the tree.trunk-onto

'János shot the arrow at the tree trunk (but the arrow didn't hit the tree trunk).'

(Surányi 2009, (30b))

Consider whether a restitutive reading is possible for this construction. A possible situation is where arrows can be shot using a bow, but they can also be thrown by hand. If the arrow is thrown first, and then shot using a bow, then only the restitutive reading is possible. In this case, (62) is not felicitous: 
(62) János megint rá lótte a nyilat a fatörzsre.

Janos again onto.it shot the arrow-ACC the tree.trunk-onto

'János shot the arrow at the tree trunk again.'

a. Repetitive: János shot the arrow at the tree trunk earlier.

b. "\#estitutive: The arrow was in the tree trunk earlier (it was thrown there by hand earlier).

The unavailability of restitutive interpretation corroborates the claim that some verbal modifiers are not resultative.

\section{Interpretation}

In the next section we return to the interpretation of repetitive adverbials. As discussed in section 1, these adverbials presuppose an earlier event of the same time. Proposed definitions differ with respect to properties of the presupposed event. For example, von Stechow (1996) requires the event to be maximal, while Beck (2005), repeated below, imposes no such requirement. The maximality requirement is problematic because repetitive adverbials can appear with atemporal predicates as well, as discussed below.

$$
\begin{aligned}
\llbracket \text { again } \rrbracket\left(P_{\langle i, t\rangle}\right)(e) & =1 \text { iff } P(e) \& \exists e^{\prime}\left[e^{\prime}<e \& P\left(e^{\prime}\right)\right] \\
& =0 \text { iff } \neg P(e) \& \exists e^{\prime}\left[e^{\prime}<e \& P\left(e^{\prime}\right)\right] \\
& \text { undefined otherwise }
\end{aligned}
$$

(Beck 2005)

I suggest that there is no unique definition of repetitive adverbials; the meaning of these elements can differ to some extent. All of them presuppose an earlier event, but they also share this property with back, still, and their crosslinguistic equivalents.

Consider some issues raised in Klein (2001). Klein notes that atemporal situations and individual-level predicates can be modified by the German repetitive wieder 'wider'. This is expected given Beck's definition, since the presupposed event does not need to end prior to the asserted event. I assume that modification of such a predicate by a repetitive is felicitous if asserting that the predicate holds is relevant for some reason. This is the reason for the various contexts discussed by Klein (2001) in section 1. For example, if different numbers are listed as prime numbers, then given a prior number that was prime, nineteen would be a prime number again. Alternatively, if there are different methods for determining if a number is prime, then the reporting the result of a subsequent test can also contain again, as the property of nineteen being a prime is is relevant. 
(64) Neunzehn ist wieder eine Primzahl.

nineteen is again a prime.number

'Nineteen is a prime number again.'

(German; Klein 2001)

I suggest that the same felicity issue is at play with the following example. According to Klein (2001), the example is odd if the current event of being on Axalp is not preceded by an interval at which we are not on Axalp.

(65) Im folgenden Herbst waren sie wieder auf der Axalp.

in.the next fall were they again on the Axalp

'Next fall, they were on Axalp again.'

(German; Klein 2001)

Not being on Axalp prior to the time of the asserted event makes the example felicitous, since the assertion is relevant. However, as shown in (66), it is not obvious if the event must be false at some prior to the asserted event.

(66) Feri alszik. Nézd, már megint alszik.

Feri sleeps look already again sleeps

'Feri is sleeping. Look, he's sleeping again.' (the speaker is not committed to Feri having woken up earlier)

Comparable Hungarian examples, shown below, behave similarly to German.

(67) a. A tizenkilenc megint prím.

the nineteen again prime

'Nineteen is prime again.'

b. Megint a Kékesen voltunk.

again the Kékes-on were.1PL

'We were on Kékes again.'

Klein (2001) argues that repetitives are relevant for the discourse level rather than fact level of the sentence. In other words, it is assertion that is relevant, not whether the event is or was true at some time. This paper cannot do justice to the data Klein (2001) discusses, including the effects of stress placement. Rather, it should be pointed out that felicity and relevance play a role in adverbial modification other than repetitives as well. For example, (68) is often judged as marked. However, if the relevant issue is the duration of the non-arrival (e.g., from the time when the arrival is expected), then the example becomes acceptable. The usual characterization is that the adverbial modifies scopes over negation - it is not necessary to 
appeal a discourse level characterization of durative adverbials to account for $(68)$.

(68) a. Fred didn't arrive for ten minutes.

b. Feri tíz percig nem érkezett meg.

Feri ten minute-until not arrived perfective

'Feri didn't arrive for ten minutes.'

Recall, in addition, that speech act-related interpretation is not available for megint in Hungarian, as shown in (16); only még egyszer 'once more' can fulfill such a role. This makes it less likely, though not impossible, that a discourse-related use is available for megint (the specific position of the discourse-related repetitive is not specified, but it may be assumed to be speech act-related). Finally, Katalin É. Kiss (p.c.) raises the possibility that examples such as (67) involve ellipsis, such as in the following example:

(69) Megint az jött ki, hogy a 19 prím.

again that came out that the 19 prime

'The result was again that 19 is prime.'

In order to fully endorse such an account, it is necessary to specify how ellipsis proceeds in such cases, including the placement of the repetitive. Exploring this treatment in such detail is, unfortunately, outside of the scope of this paper.

Based on the considerations discussed above, I assume that the definition of Beck (2005) is still appropriate for repetitives. The structural position will generally account for scope differences (but see Patel-Grosz \& Beck 2014 and Horvath \& Siloni 2011 for argument for a counterdirectional definition).

Not all repetitives have the same interpretation. Consider anew, perhaps afresh and Hungarian verbal modifier 'újra. ${ }^{16}$ These adverbials require the asserted event to start 'from scratch'; the effects of the prior, presupposed event are not relevant. Thus, (70) is false if the first version of the letter or chapter is merely revised.

(70) Feri'újra írta a levelet/fejezetet.

Feri again wrote the letter-ACC/chapter-ACC

'Feri wrote the letter/chapter again.'

${ }^{16}$ The 'from scratch' meaning does not hold for non-verbal modifier újra. This fact provides additional support to the claim that the two repetitives require distinct lexical entries. 
I suggest that the definition of these adverbials contains the requirement that the initial states $\left(s_{0}\right)$ of the presupposed and the asserted events are identical:

$$
\begin{aligned}
\llbracket \text { újra } \mathrm{VM} \rrbracket\left(P_{\langle i, t\rangle}\right)(e) & =1 \text { iff } P(e) \& \exists e^{\prime}\left[e^{\prime}<e \& P\left(e^{\prime}\right)\right] \& s_{0}(e)=s_{0}\left(e^{\prime}\right) \\
& =0 \text { iff } \neg P(e) \& \exists e^{\prime}\left[e^{\prime}<e \& P\left(e^{\prime}\right)\right] \& s_{0}(e)=s_{0}\left(e^{\prime}\right) \\
& \text { undefined otherwise }
\end{aligned}
$$

\section{The internal structure of repetitives}

This section briefly considers the morphology of the adverbials under discussion. The discussion reveals that even though repetitive adverbials are generally (historically) complex elements, their behavior is generally not predicted by the morphological makeup. The only exception is verbal modifier (but not non-verbal modifier) 'újra, where the root uj 'new' may be responsible for the 'from scratch' interpretation discussed in section 4 . A more detailed investigation of repetitive adverbials may reveal some connections between the form and the behavior of repetitives. The discussion follows Tótfalusi (2001).

Megint is judged by informants as morphologically simple. It is, however, historically complex. Megint is formed from meg + int, where meg can currently express, among others, conjunction (egy meg egy 'one plus one') and -int is a manner affix (szer+int 'according to'). Meg also had a repetitive interpretation previously, as shown below from Bolond Istók by János Arany:

(72) Történelembool ha micskét tanult is, Meg elfelejté a vizsgálatig history-from if some-ACC learned too again forgot the examination-until 'Even though he learnt a bit of history, he forgot it by the examination.'

It should be noted that a separate entry of meg, which appears as a verbal modifier, is described as having an original counter directional meaning (comparable to present-day Hungarian vissza). The remnants of this interpretation can be seen in the verbs shown below.

(73) a. $\quad$ meg + ad 'meg + give' $=$ vissza + ad 'back + give; give back, return'

b. $\operatorname{meg}+$ fordul 'meg + turn' = vissza + fordul 'back + turn; turn back'

c. $\quad$ meg + jön 'meg + come' $=$ vissza + jön 'back + come; come back'

Ismét has a number of dialectal forms which more transparently show that this repetitive also contains (repetitive) meg. These alternative forms are 
esmeg, ismég; in addition to meg, they also contain the additive is (Feri is 'Feri too/as well'). Ismét can be verbalized by the suffix -el (ismétel 'repeat'); the verb can be further affixed to derive different verb forms or a deverbal noun (ismétlés 'repetition').

Ujra is the first repetitive whose standard form is morphologically transparent. It consists of $u j$ 'new' and the sublative affix -ra 'onto'. The repetitive újfent also contains the morpheme új 'new'. According to Tótfalusi (2001), the origin of the suffix -fent is unknown; he notes that it may be related to fenn/fent 'up'.

The next two forms are clearly compositional. They contain még 'yet, still', which is derived from the conjunction meg. Egyszer 'once' is the numeral egy followed by the multiplicative suffix -szer. Mindig 'always' is derived from the quantifier mind 'all' with the suffix -ig 'to'. Finally, vissza 'back' can be seen as a simple, non-derived form.

Note that an additive component is found in most forms of repetitive adverbials in Hungarian. Without a more detailed description of the behavior of repetitives, it is not clear how the various properties, including the different readings permitted, correlate with the form of the adverbial. Note that even though újra is obviously a complex element, which transparently contains the root $u j$ 'new', even that fails to predict its properties. Comparable elements, such as English anew, can require the 'from scratch' interpretation noted in section 4, while this is absent in other forms, such as the Spanish de nuevo (lit. 'of anew'). The behavior of újra is mixed: it has the plain interpretation when it appears as an independent adverbial and has the 'from scratch' interpretation if it is a verbal modifier. Thus, once again, the morphological properties fail to predict the behavior of the adverbial.

\section{Conclusion}

This paper is an attempt at characterizing repetitive adverbials in Hungarian. The most obvious conclusion is that these adverbials - as probably almost all their crosslinguistic counterparts - are not homogeneous, but show subtle variation. The most obvious difference among the adverbials is the possible range of interpretations; different repetitive adverbials allow different scope readings. A clear example of this variation is that only megint and újra permit restitutive interpretation. This cannot be simply ascribed to the fact that the other adverbials are not decompositional, because some of the latter repetitives also allow a lower repetitive reading with causative structures. It was also noted that the interpretation of these 
adverbials can also differ. Verbal modifier újra (which is similar to English $r e$ - in many respects), as well as English anew and afresh require the initial state of the presupposed and the asserted events to be identical. No such requirement is imposed by other repetitives. Some remaining questions include a more in-depth investigation of the possible readings permitted by the repetitive adverbials and an investigation of whether the etymology of these adverbials or a decompositional analysis can predict their properties.

\section{Acknowledgements}

I would like to acknowledge the help of a number of people, including Katalin É. Kiss, Benjamin Slade, Balázs Surányi, the audiences of PLC 39 and BLINC for related discussions, and all the informants who supplied judgments and further feedback. All errors are, naturally, my own.

\section{References}

Bartos, Huba. 2011. Hungarian external causatives: Monoclausal but bi-eventive. In T. Laczkó and C. O. Ringen (eds.) Approaches to Hungarian 12: Papers from the 2009 Debrecen conference. Amsterdam \& Philadelphia: John Benjamins. 1-38.

Beck, Sigrid. 2005. There and back again: A semantic analysis. Journal of Semantics 22. $3-51$.

Cardinaletti, Anna. 2003. On the Italian repetitive prefix ri-: Incorporation vs. cliticization. University of Venice Working Papers in Linguistics 13. 7-29.

É. Kiss, Katalin. 2002. The syntax of Hungarian. Cambridge: Cambridge University Press.

Fabricius-Hansen, Cathrine. 2001. Wi(e)der and again(st). In Féry \& Sternefeld (2001, 101130).

Féry, Caroline and Wolfgang Sternefeld (eds.). 2001. Audiatur vox sapientiae: A Festschrift for Arnim von Stechow. Berlin: Akademie Verlag.

Horvath, Julia and Tal Siloni. 2011. Causatives across components. Natural Language \& Linguistic Theory 29. 657-704.

Keyser, Samuel Jay and Thomas Roeper. 1992. Re: The abstract clitic hypothesis. Linguistic Inquiry 23. 89-125.

Klein, Wolfgang 2001. Time and again. In Féry \& Sternefeld (2001, 267-286).

Lechner, Winfried, Giorgos Spathas, Artemis Alexiadou and Elena Anagnostopoulou. 2015. On deriving the typology of repetition and restitution. Paper presented at GLOW 2015 .

Patel-Grosz, Pritty and Sigrid Beck. 2014. Revisiting again: The view from Kutchi Gujarati. Proceedings of Sinn and Bedeutung 18. 303-321.

Sportiche, Dominique. 2012. Re re again. In L. Brugé, A. Cardinaletti, G. Giusti, N. Munaro and C. Poletto (eds.) Functional heads. Oxford: Oxford University Press. $253-262$. 
Stechow, Arnim von. 1996. The different readings of wieder 'again': A structural account. Journal of Semantics 13. 87-138.

Surányi, Balázs. 2009. "Incorporated" locative adverbials in Hungarian. In K. É. Kiss (ed.) Adverbs and adverbial adjuncts at the interfaces (Interface explorations 20). Berlin \& New York: Mouton de Gruyter. 39-74.

Tótfalusi, István. 2001. Magyar etimológiai nagyszótár [Etymological dictionary of Hungarian]. Budapest: Arcanum Adatbázis.

Washio, Ryuichi. 1997. Resultatives, compositionally and language variation. Journal of East Asian Linguistics 6. 1-49.

Williams, Edwin. 2011. Regimes of derivation in syntax and morphology. London: Routledge. 